\title{
Street Entrepreneurship in the Wake of Covid-19: The Dilemma of Street Vending and Strategies for Endurance
}

Submitted 21/12/20, $1^{\text {st }}$ revision 18/01/21, $2^{\text {nd }}$ revision 21/02/21, accepted 20/03/21

Daniel Chigudu ${ }^{1}$

\begin{abstract}
:
Purpose: To determine how street vendors can endure and sustain their livelihoods under the restrictive conditions of Covid-19 management in Zimbabwe. Although entrepreneurship takes a widespread conception, one of its forms is characterized by informality like street vending. Despite local authorities' attempts to designate vending areas to decongest urban centers, street vendors always attempt to find their way back to the central business districts $(C B D)$ in Zimbabwe. Designated areas are necessary, but vendors argue that they hardly get clients in those usually allocated in the peripherals. To curb CBD influx regulatory authorities, resort to stern measures like the demolition of vending stalls. This is viewed as human rights violation against people trying to make ends meet.

Design/Methodology/Approach: A hermeneutic phenomenological approach informs qualitative research through secondary data obtained from media reports, research reports, books, and speeches. Content analysis as a data analysis method was used to elicit meaning. Findings: Findings reveal that local authorities have demolished vending stalls across the country in compliance with Statutory Instrument 77 of 2020 promulgated by the government to curb the spread of Covid-19. This has left street vendors gasping for life with no alternatives for livelihood, especially when no vaccine against the pandemic is expected anytime soon.

Practical Implications: This study is useful in developing countries with high unemployment rates like Zimbabwe and the high informal sector in the form of street vending, among other means of livelihood.

Originality/Value: Under these Covid-19 excruciating circumstances, this study provides novel ideas that could benefit both this marginalized group and policymakers in the country. The recommended strategies for coping and sustaining livelihoods are given without compromising prescribed conditions to fight the pandemic.
\end{abstract}

Keywords: Covid-19, social entrepreneurship, street vending, livelihood, Zimbabwe.

JEL codes: D10, H59, K20, L10, L26, L32, L5.

Paper Type: Research Study.

${ }^{1}$ Department of Graduate and Research Studies, College of Economic Management Sciences, University of South Africa, Pretoria, South Africa, danchigudu@gmail.com 


\section{Introduction}

The entrepreneurship phenomenon, which occasionally signifies societal entrepreneurship, has received popularity and attention from researchers, opinion leaders, and policymakers. In a broad context, entrepreneurship refers to organizations and individuals engaging in entrepreneurially scholarly activities by societal objectives. Street entrepreneurs belong to this phenomenon. The concept takes various forms, including the informal sector, such as street vending, which is the thrust of this study in a Covid-19 threatening environment. In this period of Covid19 high informality poses a severe health risk. According to LFCLS (2020), the country's informal economy's employment level rose by $14 \%$ from 2014 to 2019. The labor force survey of 2019 reports that the country's informal economy, populated mainly by the informal sector, contributes $84 \%$ labor force to the country, mainly directed by women. The shadow economies report of 2018 by the IMF reveals the informal economy in Zimbabwe at $60.7 \%$ of the GDP ranking third globally, following Georgia with $64.9 \%$ and Bolivia at $62.3 \%$.

Moreover, the 2019 LFCLS (2020) shows the informal economy's employment rate $76 \%$ of the total employment. This indicates high informality levels and implications regarding the overall impact and Covid-19 spread in the country. Under the circumstances, street vendors eking out a livelihood cannot avoid their business when social protection mechanisms are not available or inadequate. Urban centers are overly congested by informal economy markets like street vendors and other informal sector workers. This vulnerable group is exposed to the low occupation, health, safety, and environments (OSHE) such as sanitation and low water, providing a breeding ground for disease carriers. Given their paltry, erratic, and insecure incomes, street vendors cannot easily access proper Covid-19 personal protective equipment (PPE) like sanitizers and masks, let alone implementing meaningful social distancing. For street vendors operating under harsh conditions with erratic or no water supplies, enhancing personal hygiene like handwashing with water and soap to prevent Covid19 infections is a big challenge.

The Zimbabwe Congress of Trade Unions (ZCTU, 2020) notes that the national lockdown announcement triggered essential commodities' stockpiling. Shortages followed while supermarkets increased their prices as they reacted to high demand, at a time when street vending was banished. This was exacerbated by South Africa's lockdown, where most businesses import essential goods. Meanwhile, human rights groups complained that the government took advantage of the Covid-19 pandemic to demolish vending stalls across the country (Kulkarni, 2020). This has left lots of street vendors who sell fruits, clothes, household items, and vegetables with no livelihood means. Street vendors do not understand why their structures have suddenly become illegal when some municipalities have levied them in the past ten years. They have previously resisted displacements since they doubted local authorities' will or capacity to construct adequate stalls for accommodating them. However, with the Covid-19 statutory lockdown, it has not been possible to mobilize themselves against 
the demolitions. The promulgation of Statutory Instrument 77 of 2020 by the government empowered local authorities to comply and demolish street vendor stalls to curb the disease's spread. This has been contested by the Zimbabwe Chamber of Informal Economy Associations (ZCIEA, 2020), describing demolitions as ruthless, inhuman, and ruthless. ZCIEA (2020) perceived this move as a form of silent torture and harassment of innocent street vendors. Each time an outbreak occurs, either typhoid or cholera and now Covid-19, the informal traders suffer the worst brunt. ZCIEA laments that "Why is the public health war on Covid-19 pandemic becoming a war on the livelihoods of the vulnerable urban poor dependent on informal trading for their livelihoods?" It is against this background as inspired by the impact of Covid19 to investigate how this sector of entrepreneurs, the street vendors, are coping with the situation and what can be done under these excruciating circumstances.

Research Question: How can street vendors endure and sustain their livelihoods under the restrictive conditions of Covid-19 management in Zimbabwe?

\section{Conceptual Framework}

To understand and appreciate street vending in Zimbabwe's informal urban areas, it is essential to underscore the interrelationship between entrepreneurship, social entrepreneurship, and street vending. One of the world's leading research projects conceived to advance understanding of the correlation between economic national development and entrepreneurship is the Global Entrepreneurship Monitor (GEM). It generates annual surveys, and in 2009 about fifty-five countries were involved (Bosma and Levie, 2009). Since its inception, the 2009 Report was the 11th of that nature reporting on the entrepreneurship status, including issues of social entrepreneurship, identifying three potential causes for the low prevalence of entrepreneurship, namely a lack of knowledge; a likely low representation by sample institutions responsible for social good; and that profit-oriented enterprises could discount themselves from the arena of entrepreneurship (Herrington, Kew, and Kew, 2009). Despite its limitations, the GEM report considers the whole range of activities across the social spectrum.

The foundation of small and medium enterprises (SMEs) is entrepreneurship, just as these enterprises arise from entrepreneurial activities. The name entrepreneurship was derived from French ahead of the general view of entrepreneurial sense. It evolved from the term entrepreneur, a French verb which means 'to undertake' according to Kuratko and Richard (2009). Back then, in the 16th century, the Frenchmen who managed and organized in the armed forces and travelled were viewed as entrepreneurs due to their hazardous and courageous activities. The term was also used to refer to some other forms of activities that were adventurous. However, entrepreneurship ought to be distinguished from other means of making money, such as wage employment and self-employment. 
Regarding formal employment, one engages in working for others for a wage or salary following some orders. Such employment has no provision of better wealth creation by itself. In this case, one has to choose from several sectors, varying from the public sector to the private sector. As regards self-employment, it is concerned with an individual's occupation who then makes action priorities.

In the economic theory, entrepreneurship is an area defined well ever since the 1911 publication of Schumpeter's seminal work (Swedberg, 2000). However, in that publication, social entrepreneurship is not a central matter in this broad theory of entrepreneurship, neither is it at the same time stated in review articles or entrepreneurship textbooks. Steyart and Hjorth (2006) assert that studies on the advance of social entrepreneurship were not carried out until recently by experts and scholars who did not naturally belong to entrepreneurship as a field. Lepoutre, Justo, Terjesen, and Bosma (2013) argue that studies in this area are illustrated by success stories and case studies lacking a base of theory and generalisability. While differences arise between ideas of a social entrepreneur, social entrepreneurship, and social enterprise (Defourny and Nyssens, 2008), the interest is related closely to the understanding that what constitutes social enterprises is United States organizations' growth (Austin, Stevenson and Wei-Skillern, 2006). Business schools and universities worldwide are presently seized with various social enterprises, social entrepreneurship, and educational programs. Accordingly, there is an increased interest in this area among practitioners and academics (Hulgård, 2010). Though the term' social entrepreneur' has a history that is not long, the social entrepreneurship practice is not new. Bornstein (2007) observes that in the late 1800s, Florence Nightingale, who modernized the hospital conditions theory together with John Durand, who initiated work for the mentally challenged people (Alter, 2007), serve as examples of those who brought social change and could be labeled as social entrepreneurs today. Nicholls (2006) argues that the concept of a social entrepreneur was initially introduced back in 1972 through some banks as it was realized that social problems could be dealt with utilizing managerial exercises.

Although social entrepreneurship, even under different names, received relevance between the 1970s-1980s, it only gained traction from academia and governments in the 1990s. Social entrepreneurship is now recognized as a new form of entrepreneurship evolving, predicated on a social creation of wealth and not the economic generation of wealth being the primary objective (Leadbeater, 1997; Dees, 1998).

Some researchers have claimed that entrepreneurship activities have economic effects to enhance growth, poverty reduction, and improve overall social development (Zahra et al., 2008). Entrepreneurship is an inter-disciplinary concept, and granting the term is broad, the meaning it usually carries differs. As a result, social entrepreneurship as a concept assumes two different contextual meanings: European and Anglo-Saxon traditions. The disparities could be attributed to the different conceptions of government's role and capitalism (Bacq and Janssen, 2011). For instance, in the case 
of Anglo Saxon, especially in the United States, social entrepreneurship often refers to broad experiences obtaining in both profit and non-profit sectors and the public sector through particular conditions whereby market stratagems are employed for income generation. As for the tradition in Europe, social entrepreneurship is seen in most cases as a different means of conducting business. Activities of social entrepreneurship imply different things in various places due to variations in the cultural and geographical contexts (Mair and Martí, 2006). However, these variations in meanings, a vital distinction resident in all the definitions, is one of a social mission being the key driving force for social entrepreneurship (Leadbeater, 1997). For entrepreneurs, the common factor is maximizing some degree of social impact, frequently meant to address a social need (Hoogendorn et al., 2010).

A social enterprise is concerned with looking for solutions to economic and sociopolitical challenges in the simplest form. Searching for solutions to socio-economic problems should not be a matter of a given private or public organization. In this world where there is a growing disconnect between the poor and the rich, it becomes the responsibility of private groups, businesses, individuals, donors, not-for-profit, and public organizations to address socio-economic problems. This is the focus of what social entrepreneurs, including street vendors, seek to do and what entrepreneurship is all about.

Street vending implies selling goods in public or regulated areas, mainly in streets, traffic control signals(robots), open spaces, street corners, and pavements where most customers patronize or are located (Graaff and Ha, 2015; Mramba, 2005). Graaff and $\mathrm{Ha} \mathrm{(2015)} \mathrm{argue} \mathrm{that} \mathrm{the} \mathrm{term} \mathrm{street} \mathrm{vending} \mathrm{is} \mathrm{every} \mathrm{day} \mathrm{in} \mathrm{academics,} \mathrm{although} \mathrm{it} \mathrm{is}$ given various names depending on a region and locality. Countries in the Anglophone use street hawkers, street peddlers, street vendors, or informal traders. In Latin American, terms like Comerciantes and Ambulantes are used. In Zimbabwe, the term street vending is used as employed in this study, including street peddling, street hawking, and informal street trading.

According to Njaya (2014), informality and particularly street vending, is usually viewed as urban informality, which is not legal, not registered, and hence not taxable. It is portrayed as an activity that disadvantaged and marginalized groups precariously practice. Graaff and $\mathrm{Ha}$ (2015) argue that street vending is informal labor best expressed as a not formal practice that evades interference from the State. In Zimbabwe, street vending comprises tomatoes, vegetables, fruits, ornaments, cell phone unlocking, bicycle repair, installation of WhatsApp on cell phones, internet, and mending, among other things (Njaya, 2014). Street vending has high mobility since vendors are usually not tied to one place as they change places periodically. It is predominantly the unemployed who engage in the street vending phenomenon. For a long time, street vending has been identified with self-employment. Lately, organizations have emerged representing this informal sector group, although their advocacy impact on vendors' worthy cause appears to have not been effective in light 
of suppression (Cardoso,2016). Street vending is a survival strategy sustaining the less privileged livelihoods, especially in the Global South.

\section{History of Street Vending}

According to the National Association of Street Vendors of India (NASVI, 2017). It was prevalent as far back as 79 A.D in the ancient Pompeii city of Italy (Flip, 2015). In the 1850s mobile vending took centre stage as people had to buy food and other merchandise while on trains and buses. Street vending became widespread up until 1936 at the time in America when Oscar Mayer started using a Weiner mobile selling meat (FLIP, 2015). From the 1930s, there was a rapid street vending increase, spreading out to urban centers in the Global South, according to Flip (2015). As observed by NASVI (2017), street vending began with merchants who travelled selling their goods from door to door back then. Perhaps medieval and ancient evolutions tolerated these vendors such that they had to flourish up to this day. Street vending regulations were first made in 1691 in New Amsterdam, later known as the New York City (FLIP,2015). During that time, the middle-class urbanites began complaining about pavements being blocked, congesting cities. This created animosity between city officials and street vendors (NASVI, 2017). The contention by Skinner (2008) is that cities in Africa are vibrant with an array of merchants selling various goods from vegetables and fruits to traditional medicine, furniture, and clothes.

In the 1990s, street vending in Zimbabwe became more pronounced following the Economic Structural Adjustment Programme (ESAP) coupled with its policies that affected many urban areas (Njaya 2014; Rogerson, 2016). In terms of street vending and sustainable livelihood, Chambers (1992) asserts that sustainability is determined if a livelihood strategy can endure shocks and stresses affecting users. In Africa in general and Zimbabwe, street vending has been given due credit for job creation as unemployment levels soar up (Ruzek, 2015). According to Benit-Gbaffou (2015), street vending is a strategy of alleviating poverty in households in many urban areas.

Hence, using repressive approaches work against the role of sustainable livelihoods for the poor, which street vending plays (Graaff and Ha, 2015). Even though allocating designated areas in the fringes of the CBD is a practice that is discriminatory in terms of controlling street vending, the practice best serves the interests of the formal sector at the expense of the informal sector. Customers seldom go out to CBD's outskirts (Huchzermeyer, 2011). Bromley (2000) cited in Rogerson (2016) that it is less cumbersome to push street vendors out of the streets to designated areas, whereas it is not easy to push their clients to those areas. Therefore, if clients cannot follow through to designated areas, street vendors justifiably remain in the streets. Street vending governance is difficult due to various perceptions between city officials and street vendors (Mitullah, 2013; Rogerson, 2016). It is everyone's right to be in town regardless of social status, but authorities apply exclusionary measures to street vending, thus violating vendors' rights (Purcell, 2002). 
The tradition of modernist urban planning informs municipalities of the policy options that negate livelihoods' perspective, which consider street vending to be a source of sustaining livelihood (Marapira, 2013).

\section{An Overview of Street Vending Governance in Africa}

Experiences inform us of the Global North, modernist planning theories, abstract informality in the urban as a legacy of the past, an indication of underdevelopment or backwardness which can only vanish with the advent of modernization (BenitGbaffou, 2017). This agrees with the dualistic approach theory that informality is a transit sector that disappears as development is realized (Kumari, 2016). The Global South has received the modernist theory in urban areas' governance, yet the theory does not hold street vending as a livelihood strategy for those poor urban people (Benet-Gbaffou, 2017; Hart, 1973; Njaya, 2014). Often, street vending is a target of harassment and evictions because of congestion concerns and issues to do with the environment (Njaya, 2014). Interrogating and reviewing the October 2013 cleaning campaign in South Africa, which was dubbed 'Operation Clean Sweep' BenetGbaffou (2014, p. 3) contends that street vendors' governance leaves a lot be desired.

As these people are "treated as human waste" they operate in very harsh conditions where city policies hardly give them recognition (Kumari, 2016). In pursuit of the modernist urban planning dimension of having clean cities, South Africa's Operation Clean Sweep saw the demolition of 7000 stalls of informal traders in Johannesburg alone (Benit-Gbaffou, 2017). Violent evictions of street vendors in Ghana as municipalities utilized cameras for tracking vendors whose operations were not in designated sites (Steel et al., 2014). The same was experienced in Namibia and Zambia back in the 1980s (Skinner, 2008). In 1988 street vendors in Lesotho got evictions when a prominent person, Pope John Paul II, arrived (Setsabi, 2006 in Skinner, 2008). Relocations and evictions of street vendors have remained a challenge in Nairobi, Kenya, when vendors occupy public space (Morange, 2015).

Street vendors in Mozambique were displaced in 2007 to an out-of-town allocated area named Muthurwa market. The country has experienced random evictions due to rules and regulations biased against street vending (Skinner, 2008). Tanzania has not been an exception where the state has applied force to remove street vendors from the city of Dar-es-Salaam to rural areas around the 1970s, according to Nnkya (2006). The government later regularised the situation by issuing out to street vendors some operating licenses in the 1990s. This has allowed vendors to conduct their business in the town center. Achieving this was possible through the Sustainable Dar-esSalaam Project (SDP), which the government introduced as a measure of protecting vendors (Nnkya, 2006).

These governance examples confirm the claims made by Skinner (2008), Potts (2007), Rogerson (2016) and Benit-Gbaffou, (2017) of extending the modernist urban planning conception to the post-modernist period. The planning approach cannot 
adequately consider poverty challenges, inequalities, and persistent unemployment characterized by the modern-day world and urban centers, particularly in the Global South (Benjamin, 2004). By and large, in Africa, vendors' operations are controlled with brutality in the nucleus of urban areas (Benet- Gbaffou, 2014).

Furthermore, Rogerson (2016) argues that Africa's urban areas serve only the middleclass's well-being and the privileged in most cases. It should, however, be acknowledged that the governance of street vending is essential for ensuring order, but the governance process should not condone the dire economic conditions prevailing as well as available options of livelihood for the poor and marginalized (Marapira, 2013). One major challenge which Africa faces in terms of policy in urban areas remains that of street vending. Policymakers are not clear whether it should continue to reel under repression or it must now be transformed and formalized (Rogerson, 2016; Marapira, 2013). The dualistic nature of street vending's informality is heroism when they (local authorities and vendors) play cat and mouse game of chasing one another and a crisis when vendors are evicted breeding governance problems. This nature of fluidity in urban informality creates hybrid governance approaches to urban planning when addressing the challenges. The bureaucratic governance revolves around the offer of informality to partnerships and harassing them out of the streets (Hart, 2010). This puts to test the principles of democracy in many of these African states.

\section{Street Vending Governance in Zimbabwe}

Street vending in Zimbabwe can be traced back to the colonial era (Dhemba,1999). However, like in some parts of the continent, the challenge is that most local authorities believe that vending, which is informal, is not legitimate. Such a perception has causes that are structural whose roots are historical. Even though there are changes in political and socio-economic conditions, the colonial period's by-laws have remained enforceable. Some of the legislation pieces include the Vagrancy Act of 1960, the Urban Councils Act of 1973, the Vendors and Hawkers By-laws of 1973, and the Town and Country Planning Act of 1946. All these were passed into law to stifle the informal sector's activities and growth (Dhemba, 1999), hawking and street vending included. Local authorities have been unable to adjust to increased designs of informality. There are governance challenges concerning street vending, among others, in urban centers (Njaya, 2014).

In May 2005, Zimbabwe's government embarked on an extensive campaign codenamed "Operation Murambatsvina," meaning an operation for restoring order or clearing out dirty, which got rid of informal jobs and informal settlements (Rogerson, 2016; Marapira, 2013; Potts, 2006). Although the operation was not targeting the street vendors per se, the operation demolished street vending infrastructure. According to Potts (2006), 'Operation Murambatsvina' was a campaign initiated by the government to enforce municipal by-laws and stop urban informality in all forms. Poor people in all urban areas were affected in significant numbers by this exercise. 
Regardless of the disapproval and denunciation by both the international and local community (Tibaijuka, 2005), the state never made attempts to re-engage the street vendors to find a common position for the benefit of all (Musoni, 2010). The operation was viewed as a radical stance taken by the ruling party after losing 2005 election votes to the main opposition in urban areas (Rogerson, 2016). As such, street vending, despite being an essential sector of the employment sector, appears not to be receiving much attention due to its political correlation. At both the national and local levels, civil society and opposition political parties took advantage of the operation to hurl attacks on government defending street vendors (Potts, 2006).

As noted by Tibaijuka (2005), it was estimated that about 2.4 million people were victims of the operation, prompting Potts (2006, p. 275) to refer to Operation Murambatsvina as "a Tsunami of the urban poor." Harare, Zimbabwe's capital city, was most affected while all other local authorities implemented it and evicted street vendors and other informal activities. Potts (2006) observes that the operation was primed to make all unemployed people return to their rural areas. When the ruling party realized the need to win most urban votes, it began to support street vending through the Zimbabwe Agenda for Sustainable Social Economic Transformation (ZIM ASSET). In contrast, local governments repress and control street vending activities (Njaya, 2014; Rogerson, 2016). Solutions to street vending challenges do not reside only in street vendors' representatives and local authorities, but the central government should also be a significant player since political leaders have to achieve economic sustainability through poverty reduction (Mramba, 2015).

\section{Methodology}

This was qualitative research to which a hermeneutic phenomenological approach was employed. Hein et al. (2001) contend that hermeneutic phenomenology is concerned with understanding texts in which research endeavours to create a profound and enriching account of an experience. In carrying out the research, the hermeneutic approach is not obliged to follow a step-by-step or systematic process (Kafle, 2011). It is based on this assumption why this study adopted this approach. Instead of a step-by-step process, it is guided in investigating street vendors' lived experiences informed more by salient details (Wilson and Hutchinson, 1991).

Here the guiding salient aspects are implementing Covid-19 prevention mechanisms in Zimbabwe and the impact on street vendors. Secondary data was collected from media reports, research reports, books, and policy statements, among others. This data was analyzed through a process of content analysis as described by Cole (1988). Cole describes content analysis as the analysis of visual communication and written messages. This method is also described as document analysis by Elo and Kynga (2008). Therefore, this data analysis method was used since content written about street vendors had to be critically analyzed through the absence of messages that could have been visually communicated. Elo and Kynga (2008) argue that, in content 
analysis, there is an inherent advantage to deal with substantial textual data volumes stemming from various sources providing corroborative evidence.

\section{Main Findings and Discussion}

The situational policy affecting street vendors in Zimbabwe is ordinarily an administrative, political, and legal function. However, in the circumstances of a pandemic like Covid-19, in this case, it is more of a legal and administrative function, yet those affected take it more to be in a political context given that Zimbabwe's urban areas are strongholds of the main opposition party. Therefore, any eviction is seen as punishment meted out to street vendors by the ruling party, notwithstanding the prevalence of Covid-19. From a legal perspective, the country has constitutional provisions related to the rights of individuals to work, private ownership of property, rights to collective public space, and socio-economic associations embracing street vendors.

Besides these provisions, Zimbabwe never had a street commerce national policy until the advent of Covid-19, which triggered the promulgation of Statutory Instrument 77 of 2020. This situation was obtained even though most urban populations derived their livelihoods from entrepreneurship, including street trading. The recognition of the pivotal role played by this sector of informal workers, especially street vendors, is of paramount importance for a country whose formal employment is shrinking.

However, elsewhere, street vending national policies have been put in place in France, India, the United States of America, and the United Kingdom, Peru, the Caribbean Islands, Bahamas, and Barbados.

In 2004, India adopted a street vending national policy, a paradigm shift from that prohibiting to regulating. Further, to bolster this street vending national policy, India's Federal government crafted and passed a Bill for the Protection of Livelihood and Regulation of Street Vending seeking to protect street vendors against wanton evictions and harassments. This Bill was a culmination of advocacy organized by organizations representing street vendors under the umbrella group NASVI.

In the early 1990s, street vendors in Dar es Salaam, Tanzania, were licensed to operate under specific guidelines. In both India and Tanzania, the guidelines are strictly enforced in light of the outbreak of Covid-19, including compliance with some other statutory requirements. In Zimbabwe, the reveals that it is only municipal regulations and by-laws apart from the recent Statutory Instrument 77 of 2020 in the governance street entrepreneurship.

These regulations and by-laws emanate invariably from processes of urban planning that have precluded street trading. Most vending sites are reportedly smoky, dusty, filthy, and ugly conditions that attract insects and rodents, hence deemed by 
municipality authorities not to be legal. The municipal by-laws should have all along not sought to eliminate street vendors but instead to set up regulatory mechanisms of street vending through licensing.

It is unthinkable how authorities have ignored such a sector to which most citizenries obtain their livelihoods. The international labor office revealed that, in general, urban public space has tended to be an issue that is highly political and involves a lot of interests (Kusakabe, 2006). In general, neoliberal and partially inclined policies to modernity result in the absolute refusal of primitive or traditional livelihood practices on sidewalks, premises of licensed shops, and pavements. Out of competition and fear, established formal retailers have lobbied municipalities to conduct evictions against the vulnerable street vendors.

Findings reveal that street vendors are perceived as competitors who are disruptive and should be banished at all costs. The Covid-19 pandemic seems to have provided a perfect opportunity to both government and local authorities to deal with street vendors decisively. Some local formal business syndicates have used their political affiliations to debar the alleged disruptive street trading competition in the past. However, state apparatus uses to install restrictions that are burdensome on street vendors during the Covid-19 without alternatives is abominable and works only for a while. Instead, the solution should encourage street vendor entrepreneurship by providing alternative enabling mechanisms than being vindictive.

With the uncertain future of the Covid-19 pandemic, the Zimbabwean government should consider adopting the formally licensed traders to the current situation where they compete with street vendors on the strength of price, quality, and service. The use of master plans adopted from the colonial era by the city fathers replicating the West's marketing concept at the expense of an impoverished society like Zimbabwean could be a mockery of sanity. In concurrence with this observation, Hart (1973) argues against the planning and implementation of an economic theory into the informal sector of an economy through a wholesome transfer of Western approaches to the cities of Africa's socio-economic structures. Street vendors have to be well integrated into the urban planning such that the available space is multi-layered and multi-functional (Kusakabe, 2006) rather than having the urban space limited only to the one function of formality ignoring informality. However, most street vendors before Covid-19 have been free riders of public utilities such as toilets, electricity, water, and urban space.

An operation for acquiring a world-class city and attracting foreign investment has led to policies threatening street vendor livelihoods. The municipalities' objective should be primarily to spruce up urban areas without prejudice to street vendors' rights. In the meantime, the street vendors' ability to sway political results in Zimbabwe is limited by their non-participation and exclusion from the process of policymaking. Street entrepreneurship policies have tended to be fluid and contingent upon the current bureaucratic and political popularity. The country's political parties 
running local authorities appear to give lip service to street vendors instead of improving their status quo and security. When elections are impending, they revive affiliation with street vendors anticipating being voted into power. The urban areas have traditionally been under the control of the main opposition party, the Movement for Democratic Change (MDC), while the Ministry responsible for Local Government and Urban.

The development has been under a Minister appointed by the ruling party ZANU-PF. This arrangement has often not boded well for street vendors whose treatment depends mainly on the stakes of politics attached to any vendors' decisions. In 2005, for instance, the state destroyed all informal sector structures under the guise of city cleaning. The main opposition party reacted angrily by attacking the state for risking the poor urban people's livelihoods. Towards elections, the same ruling party dangles some carrots in anticipation of votes in its favor. This is not a practice that is unique to Zimbabwe, as noted by Bhowmik (2005). According to Bhowmik, in most countries with large numbers of street vendors, parties in power use street vendors to gain political expediency, although the traders never get tangible benefits in the end.

Accordingly, street vending becomes extremely difficult to control and regulate when state emergencies such as a pandemic like Covid-19 take their toll (Bromley, 2000). Although street vendors across the country have had formal representations through registered associations under the Zimbabwe Chamber of Informal Associations, the groups have not spoken with one reliable voice due to the polarisation of politics and political infiltrations. When a state of emergency like this Covid-19 situation occurs, the infiltrators will be nowhere near to salvage the street vendors by providing rescue packages such as food hampers and their welfare.

In this era of the Covid-19 pandemic, 'flattening the curve' has become a catchphrase while calls for social distancing and people staying home have put emphasis unambiguously on the social inequalities even among the working class. Staying home and social distancing work best for those office workers in the middle-class under cover of social security. These prescribed conditions are not easily achieved by the informal sector workers who are not protected lying out of the bracket of formal work protections such as the national social security systems. For street vendors to survive, specific strategies have to be taken by the government, as suggested below.

\section{Strategies for Endurance}

Covid-19 prevention systems have resulted in the closing of some public spaces ordinarily used by street vendors, social interaction restrictions, disruptions in the supply chain of goods, and the collapsing of distribution networks. This has left several street vendors locked out of their only source of livelihood. Under these circumstances, specific measures have to be taken and avoid a heavy toll on this marginalized group. These measures include the extension of non-partisan social 
protection, ensuring their safety and rights, and supporting street vendors associations, as highlighted below, among others.

\subsection{Extension of Non-partisan Social Protection}

In the absence of measures that replace income sources in the informal sector, especially street vendors, they are faced with an impossible and challenging choice of letting their families go hungry or break the Covid-19 rules going out to find food and then risk sanctions or contagion. Such a scenario calls for critical measures of social protection. These include cash grants from the government to replace incomes. This could give street vendors some degree of financial relief, enabling them to practice social distancing. While public movement restrictions and physical contact become unacceptable, social protection measures become essential to keep the country's largest workforce in the informal sector out of abject poverty.

Some informal sector organizations in South Africa have already implored the government to extend the Living Cash Grant to informal workers. In Eastern Europe, HomeNet has asked for a minimum basic wage to extend to self-employed workers such as street vendors. In New York City, the Street Vendor Project has asked for an emergency universal basic income to be implemented. The Right to Food Campaign in India implored the government to distribute cash, soap, and food as a matter of urgency to the informal sector and the poor. Zimbabwe should consider assisting this marginalized group with financial aid sooner than later, irrespective of political affiliations.

\subsection{Ensuring Safety}

Most of the market and street vendors, newspaper sellers, and domestic workers in the Global South, including Zimbabwe, already had precarious working and economic conditions well before the Covid-19 crisis. Without social and legal protections, they strive to work and sustain their livelihoods taking significant risks. Street vendors who sell fresh produce in some countries have been classified as essential workers. Such countries include South Africa, Peru, and Ghana.

However, these vendors do not have easy access to public protective equipment, sanitizers, and handwashing facilities. They need protective gear together with supporting income since they are exposed to high risks. Although most street vending stalls have been demolished in Zimbabwe, street vendors always find some corners to sell their goods; hence, they should be given public protective equipment and be declared as essential workers to work in a dignified way. Safety and protection are not only necessary but also help to reduce cases of Covid-19 contagion and spreading.

\subsection{Supporting Street Vendors Associations}


Organizations for informal workers share information through various platforms such as WhatsApp groups on Covid-19 prevention measures and access food rations from donors and cash transfers. Therefore, Zimbabwe's government should link up with these organizations through the Ministry of Labour and Social Welfare and the Ministry of Health and Child Welfare to communicate pertinent information to street vendors concerning health, food handouts, and cash grants, among others. Street vendors can also communicate their welfare concerns to the government through their organizations. The organizations can quickly alert the government and civil society when some challenges that need intervention arise.

\section{Conclusion and Recommendation}

Street vending during Covid-19 and after needs to be carefully addressed through inclusive urban planning to maximize the national economy's benefits. The government must integrate the street entrepreneurship economy into the conventional national economy and ensure sustainable economic growth and development. Although the integration of street vending and informal economy into the conventional economy is not easy for a developing country like Zimbabwe, such attempts will be helpful mainly when a crisis of this nature arises. Makeshift arrangements that result in the demolition of vending stalls are necessary stopgap measures in the short run, creating long-term severe socio-economic problems.

Workable and sustainable reform strategies for a conducive business of street vending environment could allow street entrepreneurship to fizzle out of informality. A bridge has to be built when there is no crisis spanning the gap between informality and formality. This could be done through enabling frameworks passed into law by parliament and subsidiary laws crafted for various local authorities' implementation. This will safeguard the street vendors from operating at the mercy of political parties who use and abuse them willy-nilly. The informal sector associations should receive formal management training from civil society organizations to execute their mandate independent from political parties.

Survival strategies highlighted herein should not be based on patronage politics, especially when it comes to food handouts and financial bailouts. Local authorities have to ensure safe water and sanitary facilities where vending stalls are being used. Government and local authorities are obligated to regularly engage in consultations with vendors' associations to formalize street vending and provide the pandemic requirements. Consultations have also to consider designing street vending training on business development, marketing, hygiene, and food handling. It is high time the government considers street vending as an essential service as well. Further research on street vending best practices could be done in more developed countries.

\section{References:}

Alter, K. 2007. Social Enterprise Typology. Washington: Virtue Venture LLC. 
Austin, J., Stevenson, H., Wei-Skillern, J. 2006. Social and Commercial Entrepreneurship: Same, Different, or Both? Entrepreneurship Theory and Practice, 30(1), 1-22.

Bacq, S., Janssen, F. 2011. The Multiple Faces of Social Entrepreneurship: A Review of Definitional Issues Based on Geographical and Thematic Criteria.

Entrepreneurship \& Regional Development, 23, 373-403. doi:10.1080/08985626.2011.577242.

Benit-Gbaffou, C. 2015. In Quest of Sustainable Models of Street Trading Management. Lessons for Johannesburg After Operation Clean Sweep. Johannesburg: CUBES, University of the Witwatersrand.

Bhowmik, S. 2005. Street Vendors in Asia: A Review. Economic and Political Weekly. Retrieved from: http://wiego.org/sites/wiego.org/files/publications/files/Bhowmik-StreetVendors-Asia.pdf.

Bornstein, D. 2007. How to Change the World: Social Entrepreneurs and the Power of New Ideas. USA: Oxford University Press.

Bosma, N., Levie, J. 2009. Global Entrepreneurship Monitor: 2009 Executive Report. Boston,MA: Babson College.

Bromley, R. 2000. Street Vending and Public Policy. A Global Review. International Journal of Sociology and Social Policy, 20(1-2), 1-19.

Cardoso, A. 2016. Informality and Public Policies to Overcome it: The Case of Brazil. Socio. Antropol, 6(2), 322-349.

Carr, M., Chen, M. 2002. Globalisation and the Informal Economy: How Global trade and Investment Impact on the Working Poor. Geneva: International Labour Organisation. Retrieved from: http://www.ilo.org/wcmsp5/groups/public/--ed_emp/documents/publication/wcms_122053.pdf.f

Chambers, R. 1992. Sustainable Rural Livelihoods: Practical Concepts for the 21st Century. Brighton: IDS, Brighton.

Cole, F. 1988. Content Analysis: Process and Application. Clinical Nurse Specialist, 2(1), 53-57.

Dees, J.G. 1998. The Meaning of Social Entrepreneurship: Dra Report for the Kauffman Center for Entrepreneurial Leadership. Stanford University.

Defourny, J., Nyssens, M. 2008. Conceptions of Social Enterprise in Europe and the United States Convergences and Divergences. The EMES International Summer School. Corte: University of Corsica.

Elo, S., Kynga, S. 2008. The Qualitative Content Analysis Process. Journal of Advanced Nursing, 6(1), 107-115.

FLIP. 2015. We have Come Way: A Brief History of Street and Mobile Food Vending. Retrieved from: Food Liability Insurance Programme: https://www.fliprogram.com/blog/weve-come-a-long-way-a-brief-history-ofstreet-and-mobile-food vending?fb_comment_id=759306044164682_794814443947175.

Graaff, K., Ha, N. 2015.Street Vending in the Neoliberal City. A Global Perspective on the Practices and Policies of a Marginalized Economy. Berlin: Berghahn Books.

Hart, K. 1973. Informal Income Opportunities and Urban Employment in Ghana. The Journal of Modern African Studies, 11(1), 61-89.

Hein, S., Austin, W. 2001.Empirical and Hermeneutic Approaches to Phenomenological Research in Psychology: A Comparison. Psychological Methods, 6(1), 3-17. doi:10.1037/1082-989X.6.1.3. 
Herrington, M., Kew, J., Kew, P. 2009. Tracking Entrepreneurship in SA: A GEM Perspective, Cape Town: University of Cape Town, Graduate School of Business.

Hoogendorn, B., Pennings, E., Thurik, R. 2010. What Do We Know About Social Entrepreneurship: An Analysis of Empirical Research? ERIM Report Series Research in Management. International Review of Entrepreneurship, 8(2), 71112.

Huchzermeyer, M. 2014. The Urban Informal Economy: Enhanced Knowledge, Appropriate Policies and Effective Organization. In: Parnell, S., Oldfield, S. The Routledge Handbook on Cities of the Global South, 219-235.

Hulgård, L. 2010. Discourses of Social Entrepreneurship: Variations of the same Theme? European Research Network. EMES Working Papers, 1. Retrieved from: http://www.emes.net/fileadmin/emes/PDF_files/Working_Papers/WP_01_Hulg_ rd__web_.pdf.

Kafle, N. 2011. Hermeneutic Phenomenological Research Method Simplified. Bodhi: An Interdisciplinary Journal, 5, 181-200.

Kulkarni, P. 2020. Small Vendors Hard Hit by Government Ordered Demolitions in Zimbabwe. Retrieved from: https://peoplesdispatch.org/2020/04/29/smallvendors-hard-hit-by-government-ordered-demolitions-in-zimbabwe/.

Kumari, P. 201. Issues and Challenges for Street Vendors in Delhi. New Delhi: University of Delhi.

Kuratko, D., Richard, M. 2009. Entrepreneurship: Theory, Process and Practice. Mason, $\mathrm{OH}$ : South-Western Cengage Learning.

Kusakabe, K. 2006. Policy Issues on Street Vending: An Overview of Studies in Thailand, Cambodia and Mongolia. Bangkok: International Labour Office.

Leadbeater, C. 1997. The Rise of the Social Entrepreneur. London: Demos.

Lepoutre, J., Justo, R., Terjesen, S., Bosma, N.S. 2013. Designing a Global Standardized Methodology for Measuring Social Entrepreneurship Activity. The Global Entrepreneurship Monitor Social Entrepreneurship Study, 693-714. doi:10.1007/s11187-011-9398-4.

LFCLS. 2020. 2019 Labour Force Child Labour Survey Report. Retrieved from: Zimbabwe National Statistics Agency (ZIMSTAT): http://www.zimstat.co.zw/sites/default/files/img/publications/2019\%20LFCLS\% 20Report.pdf.

Mair, J., Martí, I. 2006. Social Entrepreneurship Research: A Source of Explanation Prediction, and Delight. Journal of World Business, 41(1), 36-44.

Marapira, S. 2013. Social Capital and the Informal Vendor Economy in the Dollarized Zimbabwe. International Open and Distance Learning Journal, 1(2), 9-17.

Mitullah, W. 2003. Street Vending in African Cities: A Synthesis of Empirical Findings from Kenya, Cote d'Ivoire, Ghana, Zimbabwe, Uganda and South Africa. Background Paper for the 2005 World Development Report.

Morange, M. 2015. Street Trade, Neo-liberalisation and the Control of Space: Nairobi's Central Business District in the Era of Entrepreneurial Urbanism. Journal of Eastern African Studies, 9(2), 247- 269.

Mramba, R. 2015. The Conception of Street Vending Business (SVB) in Income Poverty Reduction in Tanzania. International Business Research. Canadian Centre of Science and Education.

Musoni, F. 2010. Operation Murambatsvina and the Politics of Street Vendors in Zimbabwe. Journal of Southern African Studies, 36(2), 301-317. 
NASVI. 2017. National Association of Street Vendors of India. Retrieved from: http://nasvinet.org/newsite/wp-content/uploads/2018/09/CoOrdinator-Report.pdf.

Nicholls, A. 2006. Social Entrepreneurship: New Models of Sustainable Social Change. USA: Oxford University Press.

Njaya, T. 2014. Coping with Informality and Illegality: The Case of Street Entrepreneurs of Harare Metropolitan, Zimbabwe. Asian Journal of Economic Modelling, 2(2), 93-102.

Nnkya, T. 2006. An Enabling Framework? Governance and Street Trading in Dar es Salaam, Tanzania. In: A. Brown, Contested Space: Street Trading, Public Space and Livelihoods in Developing Cities. Warwickshire: Intermediate Technology Publications.

Potts, D. 2006. Restoring Order? Operation Murambatsvina and the Urban Crisis in Zimbabwe. Journal of Southern African Studies, 32(2), 273-291.

Rogerson, C. 2016. Responding to Informality in Urban Africa: Street Trading in Harare, Zimbabwe. Business Media Dordrecht.

Ruzek, W. 2015. The Informal Economy as a Catalyst for Sustainability. Florida State University: Department of Geography.

Sinha, S., Roever, S. 2011. India's National Policy on Urban Street Vendors. WIEGO Policy Brief (Urban Policies) No. 2. Women in Informal Employment: Globalising and Organising. Retrieved from: https://www.wiego.org/sites/default/files/publications/files/Sinha_WIEGO_PB2. pdf.

Skinner, C. 2008. The Struggle for the Streets: Processes of Exclusion and Inclusion of Street Traders in Durban, South Africa. Development Southern Africa, 25, 227 242. doi:10.1080/03768350802090709.

Steel, F., Ujoranyi, T., Owusu, G. 2014. Evictions Do Not Deter Street Traders: Case Study in Accra, Ghana. Social Science Journal, 11(2), 52-76.

Steyart, C., Hjorth, D. 2006. Entrepreneurship as Social Change. Cheltenham: Edward Elgar.

Swedberg, R. 2000. Entrepreneurship. The Social Science View. Oxford: Oxford University Press.

Tibaijuka, A. 2005. Report of the Fact-finding Mission to Zimbabwe to Assess the Scope and Impact of Operation Murambatsvina by the UN Special Envoy on Human Settlements Issues in Zimbabwe. Retrieved from: www.un.org/News/dh/infocus/Zimbabwe/Zimbabwe_rpt.pdf.

Wilson, H., Hutchinson, S. 1991. Triangulation of Qualitative Methods: Heideggerian Hermeneutics and Grounded Theory. Qualitative Health Research, 1, 263-276. doi:.org/10.1177/104973239100100206.

Zahra, S.A., Rawhouser, H.N., Bhawe, N., Neubaum, D.O., Hayton, J.C. 2008. Globalization of Social Entrepreneurship Opportunities. Strategic Entrepreneurship Journal, 2(2), 117-131.

ZCIEA. 2020. ZCIEA PRESS Statement on the Horrible Descruction of Vendors' Stalls During COVID-19 Lockdown. Harare: Zimbabwe Chamber of Informal Association.

ZCTU. 2020. ZCTU Response to the Impact of COVID-19 Pandemic on Workers and the Zimbabwean Economy. Harare: Zimbabwe Congress of Trade Unions. 